\title{
Ecosystem Carbon Stock of Mangroves at the Batticaloa Lagoon, Sri Lanka
}

\section{Kodikaraarachchige Anthoney Roshan Samantha Perera ${ }^{1}$, Mala Damayanthi Amarasinghe ${ }^{2}$}

${ }^{1}$ Department of Botany, The Open University of Sri Lanka, Nawala, Sri Lanka

${ }^{2}$ Department of Botany, University of Kelaniya, Kelaniya, Sri Lanka

\begin{abstract}
Mangroves play an important role in sequestering organic carbon in tropical and subtropical coastal areas, accounting up to $15 \%$ of the total carbon deposited in coastal sediments. Sequestered organic carbon occurs both in standing plant biomass, as well as in the below ground root biomass and mangrove soils. Unavailability of quantitative data on carbon retention capacity of Sri Lankan mangrove ecosystems compelled the authors to carry out the present study with the objective of estimating the total ecosystem carbon content in mangrove eco systems in the Batticaloa lagoon, Sri Lanka. This is the largest lagoon situated on the east coast and the third largest brackish water system in the country. Data on vegetation
\end{abstract}

\footnotetext{
* Corresponding should be addressed to Dr. K. A. R. S. Perera, Department of Botany, The Open University of Sri Lanka, Nawala, Sri Lanka

Email: kaper@ou.ac.lk

(D) https://orcid.org/0000-0003-3387-8148

(Received 18 $8^{\text {th }}$ August 2018; Revised $16^{\text {th }}$ October 2018; Accepted 29 ${ }^{\text {th }}$ October 2018) (C) OUSL

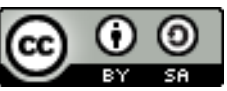

This article is published under the Creative Commons Attribution-Share Alike 4.0 International License (CC-BY-SA). This license permits use, distribution and reproduction in any medium; provided it is licensed under the same terms and the original work is properly cited.
} 
structure were gathered according to the standard procedures and biomass of mangrove trees was determined by the Allometric method. Total Organic Carbon (TOC) in three depths, $(0-15 \mathrm{~cm}, 16-30 \mathrm{~cm}$ and $31-45 \mathrm{~cm}$ ) of mangrove soils was determined by dichromate-oxidation method followed by colorimetry. Total mangrove plant biomass was found to be $298 \mathrm{Mg} \mathrm{ha}^{-1}$, of which $246 \mathrm{Mg} \mathrm{ha}^{-1}$ was in the above ground components of the plants while $52 \mathrm{Mg}^{\mathrm{M} \mathrm{a}^{-1}}$ was in the below ground components. TOC embedded in biomass was calculated to be $158 \mathrm{Mg} \mathrm{C}$ ha-1 out of which $131 \mathrm{Mg} \mathrm{C}^{-1} \mathrm{ha}^{-1}$ was found to occur in above ground and $27 \mathrm{Mg} \mathrm{C}$ ha-1in below ground components. TOC in mangrove soils (up to $45 \mathrm{~cm}$ depth) was revealed to be $348 \mathrm{Mg} \mathrm{C}^{-}$ha1. The total TOC of mangrove ecosystems in the Batticaloa lagoon was calculated to be $506 \mathrm{Mg} \mathrm{C}^{\text {ha-1 }}$. Mangrove soils that sequester $68 \%$ of the organic carbon forms the largest fraction of the mangrove carbon sink. Below ground components account for only $5 \%$ of the total pool while the above ground biomass retains five times more $(26 \%)$ carbon than the root biomass. These results assist pragmatic evaluation of ecological value of mangroves and justify their conservation and management.

Key words: Sri Lankan mangroves; carbon sequestration; soil carbon sinks

\section{Introduction}

Mangroves rank among the most carbon rich ecotone-ecosystems that occur along tropical and subtropical coastlines. Due to their relatively high primary productivity and anaerobic conditions in the inter-tidal soil/ sediment, they occupy an important role in carbon sequestration in intertidal environment (Komiyama et al., 2008; Donato et al., 2011; Hoque et al., 2011). While occupying only a small percentage $(<0.1 \%)$ of earth's surface, mangroves are responsible for $10-11 \%$ of the total export of carbon to the ocean and for $8-15 \%$ of the carbon deposited in coastal sediment (Dittmar et al., 2006; Joshua et al., 2012; Jennerjahn \& Ittekkot, 2002). Mangroves sequester organic carbon, in above ground plant biomass, below ground root biomass and also in soil (Alongi, 2011; Kauffman et al., 2011; World Bank, 2011). As nearly as half the biomass in trees contains carbon and large amounts of carbon are potentially stored in mangrove forests and therefore, they may be the largest stores of carbon in coastal zones (Suratman, 2008; Perera \& Amarasinghe, 
2016). It is estimated that carbon sequestration capacity of global mangroves is approximately 25.5 million tons of carbon per year (Ong, 1993).

The coastline of Sri Lanka is approximately $1600 \mathrm{~km}$ long and a narrow intertidal belt created by micro tidal conditions with tidal amplitude less than $1 \mathrm{~m}$ (Wijeratne, 2007). Total estimated brackishwater area of Sri Lanka is about 15800 ha (Karunathilake, 2003) and it hosts several ecosystems including mangroves that extend over an area of 15670 ha, interspersed along the coastline (Edirisinghe et al., 2012). Mangrove vegetation in Sri Lanka comprises twenty-three (23) true mangrove species and thirty-four mangrove associated plant species (Amarasinghe \& Perera, 2017).

Available knowledge on carbon sequestration capacity of tropical ecosystems in Sri Lanka is scanty. Limited records are available on the standing stock of carbon in a few man-made ecosystems in Sri Lanka, i.e 90 - $104 \mathrm{t} \mathrm{ha}^{-1}$ in home gardens (Dissanayake et al., 2009),63 $\mathrm{t} \mathrm{ha}^{-1}$, carbon in soils of coconut plantations in the wet climatic zone,54 $\mathrm{t} \mathrm{ha}^{-1}$ in the, intermediate zone and $37 \mathrm{t} \mathrm{ha}^{-1}$ in the dry zone (Chokkalingam \& Vanniarachchy, 2011). A few records are available on above ground biomass of mangroves of Sri Lanka. Dayarathne \& Kumara (2013) reported the above ground biomass (68.7-201.8 t ha $^{-1}$ ) of Rekawa mangroves, and Gunawadena et al., (2016) reported the above ground biomass estimation (of mangroves located in Negombo - Muthurajawela wetland in Sri Lanka using ALOS PALSAR Images (33-155 $\mathrm{t} \mathrm{ha}^{-1}$ with overestimation of $17 \%$ ). The present study therefore was conducted with the objective of quantifying the total ecosystem carbon content, including above and below ground plant component and soils of mangrove ecosystem in the Batticaloa lagoon. 


\section{Materials and method}

\section{Study area and sites}

Batticaloa lagoon lies between 70 24'- 70 46' N and $81^{\circ} 35^{\prime}-81^{\circ} 49^{\prime} \mathrm{E}$, and is the largest lagoon in the east coast and the third largest brackish water system in Sri Lanka (JUGAS Ltd. (2010). This lagoon extends over 11500 ha and connects with the Indian Ocean at two locations through narrow channels. Sand bars formed due to coastal sedimentation processes serves the lagoon-ocean connection causing changes of the water salinity from 0-30 mgl-1 (Harris \& Vinobaba, 2013). The mean annual temperature is $30^{\circ} \mathrm{C}$ which varies from $18^{\circ} \mathrm{C}$ to

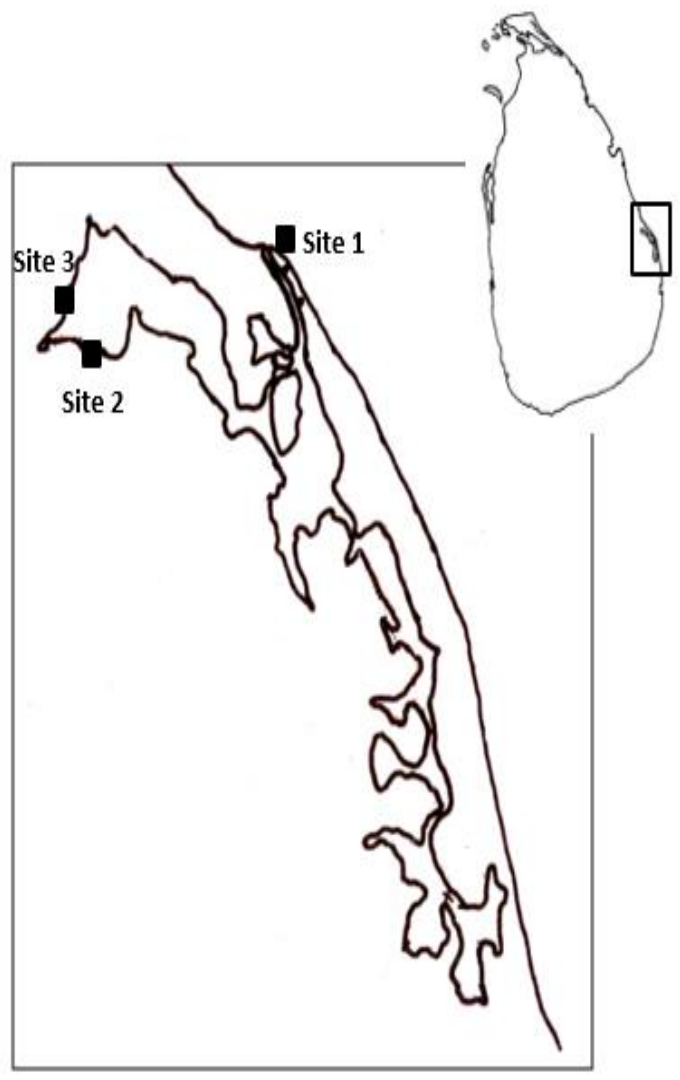

Figure. 1. Locations of study sites at Batticaloa lagoon

$38^{\circ} \mathrm{C}$ while the annual rainfall varies within $864-3081 \mathrm{~mm}$ with an average of $1500 \mathrm{~mm}$ (Kotagama et al., 1989). The extent of mangrove vegetation reported from the area is approximately 1550 ha and they are restricted mostly to the northern end of the lagoon (Rajeeshan $\&$ Jayasingam, 2000). Therefore, three (3) study sites (Site 1, Site2 and Site 3) from northern part of the Batticaloa lagoon were selected for the study (Fig. 1). Minimum distance between two study sites was at least $2 \mathrm{~km}$.

\section{Sampling Strategy}

In order to gather data on mangrove vegetation structure, including biomass and Total Organic Carbon (TOC) content in mangrove soil, $10 \mathrm{~m}$ wide belt transects were laid perpendicular to the shoreline at randomly selected locations in the selected study sites. Length of a transect at each site was determined by the width of the mangrove 
area and visual heterogeneity of the mangrove vegetation. Total of five (5) transects, one at study Site 1 and two each at Sites 2 and 3 were laid. Maximum lengths of the transects were, 20m in Site 1,30m in Site 2 and 30m in Site 3. Each transect was divided in to $10 \mathrm{~m} \mathrm{x} 10$ $\mathrm{m}\left(100 \mathrm{~m}^{2}\right)$ sub- plots and thus a total of twelve (12) sampling plots, within three (3) study sites were used for sampling. All mangrove trees in the plots were identified, numbered and mapped.

\section{Vegetation Structure}

Standard methods were adopted to quantify the major structural variables of the mangroves stands (Cintron \& Novelli, 1984, Kathiresan \& Khan, 2010), i.e. species richness, tree diameter at breast height $(\mathrm{dbh})$ and tree height of the mangrove stands were gathered from each study plot $\left(100 \mathrm{~m}^{2}\right)$ in the belt transects. Plants with a stem girth, less than $2.5 \mathrm{~cm}$ were excluded.

Complexity Index (CI), was calculated to determine the structural complexity of the vegetation (Holdridge et al., 1971; Kathiresan \& Khan 2010; Perera et al., 2013; Perera \& Amarasinghe 2016). CI was calculated using data on the number of species, stand density, basal area and height.

$\mathrm{CI}=$ Number of species $\mathrm{x}$ stand density $\mathrm{x}$ stand basal area $\mathrm{x}$ stand height $\times 10^{-5}$

\section{Biomass and Total Organic Carbon (TOC) content in mangrove vegetation}

Allometric equations derived for individual species as well as common equations were used to determine the above ground biomass and below ground biomass of mangrove species encountered in the study plots.

The allometric equations of $\mathrm{AGB}=0.289(\mathrm{dbh})^{2.327}$ and $\mathrm{BGB}=0.100$ $(\mathrm{dbh})^{2.364}$ were used to calculate the above ground biomass (AGB) and below ground biomass (BGB) of Bruguiera gymnorrhiza. The allometric equation, $\mathrm{AGB}=0.114(\mathrm{dbh})^{2.523}$, was used to calculate the above ground biomass (AGB) of Lumnitzera racemosa while below ground biomass $(\mathrm{BGB})$ was computed with $\mathrm{BGB}=0.118(\mathrm{dbh})^{2.063}$ (Perera et al., 2012). The above ground biomass of Rhizophora mucronata and Avicennia marina was calculated with $\log _{\mathrm{e}}(\mathrm{AGB})=$ $6.247+2.64 \log _{e}(\mathrm{dbh})$ and $\log _{\mathrm{e}}(\mathrm{AGB})=5.551+2.153 \log _{\mathrm{e}}(\mathrm{dbh})$ respectively (Amarasinghe $\&$ Balasubramaniam, 1992). The biomass 
of other species in the sample plots were calculated using common equations, i.e. $\mathrm{AGB}=0.251 \rho \mathrm{dbh}^{2.46}$ and $\mathrm{BGB}=0.199 \rho 0.899 \mathrm{dbh}^{2.46}$ ( $\rho$ - density of wood) (Komiyama et al., 2005). Standing stock of biomass values were then converted to the TOC values with the percentage TOC content in biomass of each plant component of mangrove species (Perera \& Amarasinghe, 2016).

\section{Total Organic Carbon (TOC) content in mangrove soil}

A split core sampler/auger 77801 (2" x12') was used to collect soil samples. Soil samples were taken from a minimum of five randomly selected sites in each study plot $\left(100 \mathrm{~m}^{2}\right)$. Samples were collected from depths of $0-15 \mathrm{~cm}, 16-30 \mathrm{~cm}$ and $31-45 \mathrm{~cm}$. Composite soil samples were prepared for each depth. Soil samples were air-dried, and oven dried at $60^{\circ} \mathrm{C}$ for constant weight.

\section{Chemical analysis}

Total Organic Carbon (TOC) content in composite soil samples was determined using the standard wet dichromate oxidation technique, without external procedure (Anderson and Ingram, 1998; Schumacher, 2002). $\mathrm{K}_{2} \mathrm{Cr}_{2} \mathrm{O}_{7}$ Solution was used to oxidize the TOC in acid medium. The amount of oxidized carbon in the sample was measured by determining the number of chromic ions produced during oxidation. Produced chromic ion concentration was determined using UV-visible spectrophotometer (Spectro UV-VIS Double Beam UVD-3000) at $600 \mathrm{~nm}$ absorbance.

Because of the incomplete oxidation of organic carbon and partially digest organic carbon in to elemental carbon forms, a correction factor was applied to elevate the accuracy of the results through adjusting the organic carbon recovery. As mean oxidation factor, 0.74 was used for the purpose.

$\%$ organic carbon $=(\mathrm{K} \times 0.1) /(\mathrm{W} \times 0.74)$

$\mathrm{K}=$ corrected concentration; $\mathrm{W}=$ Weight of the sample

A standard curve was plotted between absorbance and chromic ion concentration and it was used to obtain the carbon content in soil samples and in the blanks. The mean blank value was subtracted from the unknowns, which used as the value of corrected concentration, $(\mathrm{K})$. The bulk density of soils in three depths $(0-$ $15 \mathrm{~cm}, 16-30 \mathrm{~cm}$ and $31-45 \mathrm{~cm}$ ) at the Batticaloa mangrove areas was determined with standard methods (Anderson \& Ingram, 1998). 


\section{Results}

\section{Mangrove vegetation structure}

A statistically significant difference was not observed between the basic vegetation structural data gathered from sub plots in the study sites and therefore, they were pooled to analyze the structure of mangrove vegetation in the Batticaloa lagoon.

Relatively high stand density (4754 trees/ha) and low species composition were revealed in the mangrove ecosystems in the Batticaloa lagoon. Only three to four true mangrove species were encountered in the subplots $\left(100 \mathrm{~m}^{2}\right)$ were used for the study. Excoecaria agallocha (3470 trees/ha) and Rhizophora apiculata (1054 trees/ha) were the most abundant mangrove species in the area (Table 1). E. agallocha recorded the highest basal area and the tree height among other species found in the area.

Table 1. Vegetation structural variables recorded from the study sites at the Batticaloa lagoon

\begin{tabular}{|c|c|c|c|c|c|c|c|}
\hline \multicolumn{2}{|c|}{ Sampling area } & \multirow{2}{*}{ 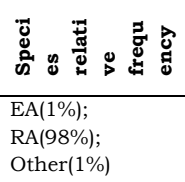 } & \multirow{2}{*}{ 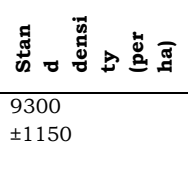 } & \multirow{2}{*}{ 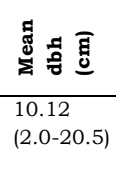 } & \multirow{2}{*}{ 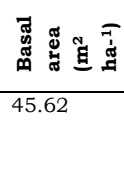 } & \multirow{2}{*}{ 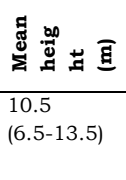 } & \multirow{2}{*}{ 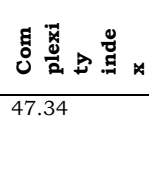 } \\
\hline$\stackrel{0}{*}$ & Transect 1 & & & & & & \\
\hline \multirow{2}{*}{$\begin{array}{l}N \\
\stackrel{2}{*} \\
\stackrel{H}{2}\end{array}$} & Transect 2 & $\begin{array}{l}\text { EA(99\%); } \\
\text { Other(1\%) }\end{array}$ & $\begin{array}{l}4350 \\
\pm 510\end{array}$ & $\begin{array}{l}6.68 \\
(2.0-22.0)\end{array}$ & 24.24 & $\begin{array}{l}4.83 \\
(2.0-9.0)\end{array}$ & 11.77 \\
\hline & Transect 3 & $\begin{array}{l}\text { EA(79\%); } \\
\text { RA(20\%); } \\
\text { Other(1\%) }\end{array}$ & $\begin{array}{l}2200 \\
\pm 260\end{array}$ & $\begin{array}{l}8.00 \\
(1.6-35.0)\end{array}$ & 22.30 & $\begin{array}{l}7.89 \\
(2.0-11.0)\end{array}$ & 14.76 \\
\hline \multirow{2}{*}{ 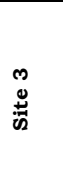 } & Transect 4 & $\begin{array}{l}\text { AM(8\%); } \\
\text { EA(85\%); } \\
\text { RA(7\%) }\end{array}$ & $\begin{array}{l}5166 \\
\pm 630\end{array}$ & $\begin{array}{l}7.95 \\
(1.8-32.0)\end{array}$ & 34.35 & $\begin{array}{l}6.36 \\
(2.5-11.0)\end{array}$ & 41.82 \\
\hline & Transect 5 & $\begin{array}{l}\text { AM(5\%); } \\
\text { EA(92\%); } \\
\text { RA(3\%) }\end{array}$ & $\begin{array}{l}4800 \\
\pm 545\end{array}$ & $\begin{array}{l}7.59 \\
(3.0-43.0)\end{array}$ & 32.27 & $\begin{array}{l}5.31 \\
(2.5-9.5)\end{array}$ & 19.01 \\
\hline \multicolumn{2}{|c|}{ Mean for entire study area } & $\begin{array}{l}\text { EA(73\%); } \\
\text { RA(22\%); } \\
\text { AM(4\%); } \\
\text { Other(1\%) }\end{array}$ & $\begin{array}{l}4754 \\
\pm 590\end{array}$ & $\begin{array}{l}8.14 \\
(1.8-43.0)\end{array}$ & 30.01 & $\begin{array}{l}6.6 \\
(2.0-13.5)\end{array}$ & 27.52 \\
\hline
\end{tabular}

AM- Avicennia marina, EA- Excoecaria agallocha, LR- Lumnitzera racemosa, RA- Rhizophora apiculata

*The mean follows standard error $( \pm)$; Range of the values are presented within parentheses 


\section{Biomass and Total Organic Carbon (TOC) content}

A statistically significant difference was not observed $(p>0.05)$ in the biomass and TOC values recorded from the study plots in the three study sites. Therefore, the data were pooled to calculate the mean values for biomass and TOC of the mangrove plants in the Batticaloa lagoon (Table 2).

Table 2. Mangrove biomass and Total Organic Carbon (TOC) content (above and below ground) values recorded in the study sites at the Batticaloa lagoon

\begin{tabular}{|l|l|l|l|l|l|l|}
\hline \multirow{2}{*}{ Sampling area } & \multicolumn{3}{|c|}{ Biomass (Mg ha-1) } & \multicolumn{2}{c|}{$\begin{array}{c}\text { Total organic carbon (TOC) } \\
\text { content } \\
\text { (Mg C ha }\end{array}$} \\
& \multicolumn{2}{|c|}{ ) } \\
\cline { 2 - 7 } & $\begin{array}{c}\text { Above } \\
\text { ground }\end{array}$ & $\begin{array}{c}\text { Below } \\
\text { ground }\end{array}$ & Total & $\begin{array}{c}\text { Above } \\
\text { ground }\end{array}$ & $\begin{array}{c}\text { Below } \\
\text { ground }\end{array}$ & Total \\
\hline \multirow{2}{*}{ Study Site 1 } & 346.49 & 73.86 & 420.35 & 193.93 & 40.02 & 233.95 \\
& \pm 2.95 & \pm 0.55 & \pm 3.56 & \pm 2.33 & \pm 0.36 & \pm 2.68 \\
\hline Study Site 2 & 154.16 & 33.08 & 187.24 & 78.10 & 16.19 & 94.29 \\
& \pm 1.56 & \pm 0.26 & \pm 1.83 & \pm 0.51 & \pm 0.20 & \pm 0.81 \\
\hline Study Site 3 & 238.68 & 49.87 & 288.55 & 122.78 & 24.69 & 147.47 \\
& \pm 2.43 & \pm 0.34 & \pm 2.76 & \pm 1.70 & \pm 0.23 & \pm 1.94 \\
\hline Mean for entire & 246.44 & 52.27 & 298.71 & 131.60 & 26.96 & 158.57 \\
study area & \pm 2.03 & \pm 0.33 & \pm 2.37 & \pm 1.62 & \pm 0.26 & \pm 1.87 \\
\hline
\end{tabular}

*The mean follows standard error $( \pm)$

\section{Total Organic Carbon (TOC) content in mangrove soil}

The highest values for the percentage TOC content in mangrove soil (5.55-7.30; mean=6.10) was recorded at $16-30 \mathrm{~cm}$ depth layer and followed by $31-45 \mathrm{~cm}$ depth layer (5.91-5.88; mean=5.89). The lowest percentage values $(4.86-5.80$; mean $=5.26)$ for TOC was in the top soil layer (0-15 cm depth). Summary of the TOC data of the mangrove soils in the Batticaloa lagoon is presented in Table 3. 
Table 3. Summary of the Total Organic Carbon (TOC) distributed among the different depth of mangrove soils at the Batticaloa lagoon

\begin{tabular}{llll}
\hline & $\begin{array}{l}\text { Depth 1 (0-15 } \\
\mathrm{cm})\end{array}$ & $\begin{array}{l}\text { Depth 2 (16-30 } \\
\mathrm{cm})\end{array}$ & $\begin{array}{l}\text { Depth 3 (31-45 } \\
\mathrm{cm})\end{array}$ \\
\hline \% TOC & $5.26 \pm 0.50$ & $6.10 \pm 0.52$ & $5.89 \pm 0.43$ \\
Bulk density & $1.37 \pm 0.02$ & $1.30 \pm 0.02$ & $1.36 \pm 0.02$ \\
$\begin{array}{l}\text { TOC weight }(\mathrm{Mg} \\
\text { ha }\end{array}$ & $108.06 \pm 10.07$ & $119.35 \pm 10.46$ & $120.42 \pm 8.56$ \\
\hline
\end{tabular}

*The mean follows standard error $( \pm)$

The lowest values of TOC contents (99.50 -123.33 $\mathrm{Mg} \mathrm{C} \mathrm{ha-1)} \mathrm{were}$ recorded at first $10 \mathrm{~m}$ zone from estuarine waterfront. Over-all TOC content revealed increased with estuarine shoreline to landwards (Fig. 2).

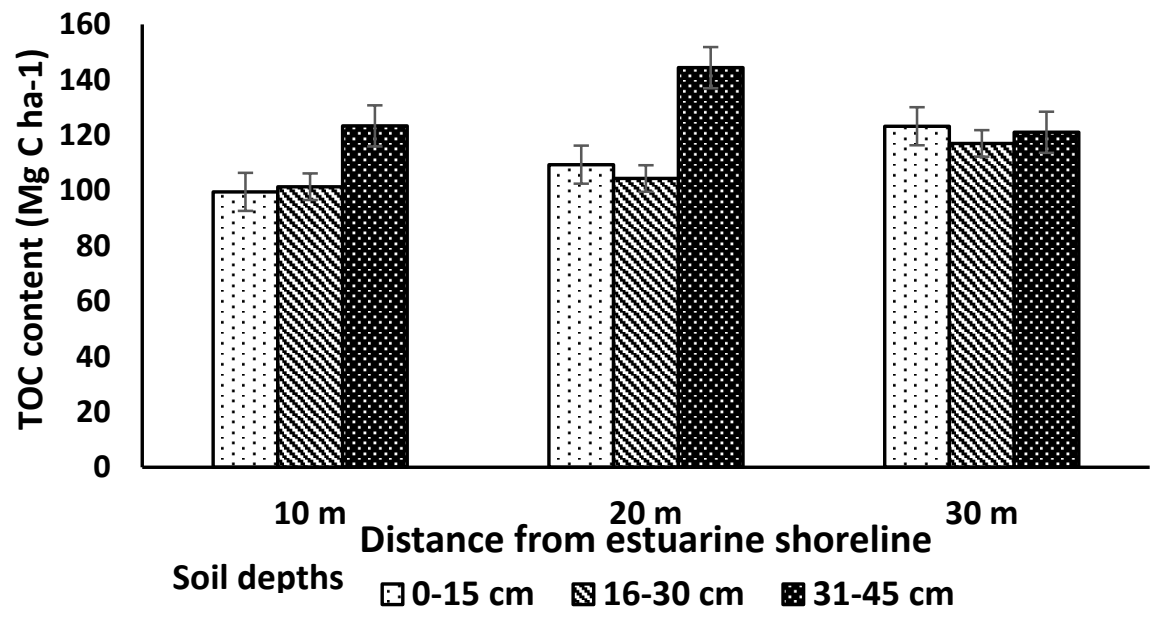

Figure 2. TOC contents of mangrove soil along the water-land gradient.

The TOC stock retained by the mangrove ecosystem was $506.40 \mathrm{Mg} \mathrm{C}$ ha $^{-1}$. Soil contained $70 \%$ of the TOC stock while $25 \%$ was in above ground and $5 \%$ in the below ground components of mangrove plants (Table 4). 
Table 4. Calculated Total Organic Carbon (TOC) content in mangrove ecosystem at the Batticaloa lagoon

\begin{tabular}{|c|c|c|}
\hline \multirow{3}{*}{$\begin{array}{l}\text { TOC in Mangrove plants } \\
\left(\mathrm{Mg} \mathrm{C}^{-1} \mathrm{~h}^{-1}\right)\end{array}$} & $\begin{array}{l}\text { Above ground } \\
\text { components }\end{array}$ & $131.60 \pm 1.62(25.98 \%)$ \\
\hline & $\begin{array}{l}\text { Below ground } \\
\text { components } \\
\text { (roots) }\end{array}$ & $26.96 \pm 0.26(5.31 \%)$ \\
\hline & Total & $158.57 \pm 1.87(31.30 \%)$ \\
\hline \multicolumn{2}{|c|}{ TOC in Mangrove soil $\left(\mathrm{Mg} \mathrm{C} \mathrm{ha}^{-1}\right)$} & $347.83 \pm 33.80(68.68 \%)$ \\
\hline \multicolumn{2}{|l|}{ Total (Mg C ha-1) } & $506.40 \pm 36.04$ \\
\hline
\end{tabular}

${ }^{*}$ Standard error is in the parentheses

\section{Discussion}

Contrary to the common occurrence of Rhizophora mucronata and Avicennia marina in most Sri Lankan mangrove ecosystems in the dry zone coastal regions and mangroves of the Batticaloa lagoon are dominated by Rhizophora apiculata and Excoecaria agallocha which are often found inter-tidal areas of low salinity (Table 1). This may be due to the differences in micro climatic and environmental circumstances prevailing in the Batticaloa lagoon, especially with respect to soil salinity (Perera et al., 2013). Mangrove communities often exhibit distinct patterns of species distribution performance efficiencies depending on tolerance levels in each plant species to environmental conditions, especially soil salinity and anoxic conditions caused by inundation regimes (Joshi \& Ghose 2003, Alongi, 2009). Some species such as A. marina do not grow in fresh water and may be considered as an obligate halophyte. High salinity tolerance of $A$. marina has been reported to possess successive of cambia that form internal phloem tissues which can store water and also repair embolism through formation of new vascular cells (Roberts et al, 2011) Others, such as E. agallocha, survive well in fresh water and may not have obligatory requirement for salt beyond trace amounts (Clough,1992). Under natural conditions, mangroves exhibit clear tolerance differences among species. Based on the reports of salinity tolerance levels of mangrove species (Clough,1992; Joshi \& Ghose 2003; Perera et al., 2013), it was revealed that most of 
the low salt tolerance species dominate the Batticaloa mangrove ecosystem.

Estimates of standard biomass both in above and below ground components provide insights into carbon allocation in plants, which is a vital information regarding local as well as regional carbon accounting or sequestration (Kairo et al., 2008). Total biomass in plants of mangrove ecosystem in the Batticaloa lagoon was estimated as $298.71 \mathrm{Mg} \mathrm{ha}^{-1}$, out of which $246.44 \mathrm{Mg}^{1} \mathrm{Ma}^{1}$ was in above ground and $52.27 \mathrm{Mg}^{-1} \mathrm{~h}^{-1}$ below ground components. The amount of Total Organic Carbon (TOC) content embedded in plant biomass was calculated to be $158.57 \mathrm{Mg} \mathrm{C}$ ha ${ }^{1}$ out of which $131.60 \mathrm{Mg} \mathrm{C}^{-1}$ was in the above ground and $26.96 \mathrm{Mg} \mathrm{C}^{-1}$ in the belowground parts of plants (Table 2).The total standing biomass (298.71 $\mathrm{Mg} \mathrm{ha}^{-1}$ ) of mangrove ecosystems in the Batticaloa lagoon therefore is greater than that in the Negombo estuary (163.72 $\mathrm{Mg} \mathrm{ha}^{-1}$ ) located in the wet zone (Perera \& Amarasinghe, 2016) and that in the Rekawa lagoon (62.4 - $\left.201.8 \mathrm{Mg} \mathrm{ha}^{-1}\right)$ situated in the intermediate climatic zone (Dayarathne \& Kumara, 2013). Although some mangroves around the Batticaloa lagoon are destroyed for anthropogenic reasons, the areas investigated in the present study were minimally disturbed (particularly the Sites 2 and 3) due to their remote location where the human population density is low. Remote location with poor accessibility and low human density may have saved these mangroves and their carbon sequestration capacity unlike those in the wet and intermediate zones that are located close to urbanized coastal centers.

Although above ground mangrove biomass has been studied during the past few decades (Kusmana et al., 1992; Ross et al., 2001; Coronado-Molina et al., 2004; Amarasinghe \& Balasubramaniam, 1992), studies on mangrove biomass which is below ground are scanty (Komiyama et al., 2008; Poungparn, 2003; Comley \& McGuinness, 2005). Considering the available records of mangrove above and below ground biomass in tropical and subtropical regions, the highest above ground biomass (460 t/ha) has been recorded for $R$. apiculata dominated mangrove forests (cultivated) in Matang, Malaysia (Putz \& Chan, 1986), and the lowest (40.7 t/ha) for mangroves of East Sumatra, Indonesia which features similar species (Kusmana et al., 1992). On average, above ground biomass of mangrove values range between 280 t/ha (from Southern Ranong, 
Thailand) (Tamai, et al., 1986) and 108 t/ha (from Okinawa, Japan) (Suzuki \& Tagawa, 1983). The above ground biomass of mangroves in the Batticaloa lagoon (246.44 $\mathrm{Mg} \mathrm{ha}^{-1}$ ), can therefore be ranked relatively high among other published reports on mangrove areas in the Asian region.

Below ground biomass (BGB) calculated for mangrove ecosystems in the Batticaloa lagoon (52.27 $\mathrm{Mg} \mathrm{ha}^{-1}$ ) falls in between the highest BGB estimated for mangroves in the Southern Ranong, Thailand (272.9 $\left.\mathrm{Mg} \mathrm{ha}^{-1}\right)$ and the lowest recorded from Southern Peng-nag (28.0 Mg ha $^{-1}$ ) in the same country (Komiyama, et al., 2008; Poungparn, 2003).

According to findings of the present study, total biomass (above and below-the-ground) in the Batticaloa mangroves range between 187 $420 \mathrm{Mg} \mathrm{ha}^{-1}$ with an average of $259 \mathrm{Mg} \mathrm{ha}^{-1}$ which can be considered relatively a high biomass value for a tropical ecosystem. Pattern of biomass distribution in mangroves throughout the tropics indicate that higher values occur at lower latitudes (Twilley et al, 1992). The maximum potential biomass is found in mangrove areas located between $10^{\circ}$ and $35^{\circ}$ north and south and it is about 100 and $400 \mathrm{t}$ ha $^{-1}$ and solar energy represents a major constraint on the distribution of mangrove biomass across the latitudes (Twilley et al, 1992).

The average content of Total Organic Carbon (TOC) in mangrove with soils up to a depth of $45 \mathrm{~cm}$ was estimated to be $348 \mathrm{Mg} \mathrm{C} \mathrm{ha}^{-1}$. The general pattern of distribution of TOC in tropical forests has been reported to be a decreasing trend with increasing depth (Grace et al, 2006; Ceron-Breton et al., 2011; Banerjee, et al., 2013). A reverse trend was observed in mangroves in the Batticaloa lagoon where the \%TOC increases with soil depth (Table 3). This may be due to the sandy sediments in the mangrove forest floor, which accounts for relatively a high bulk density values $\left(1.3 \mathrm{~g} \mathrm{~cm}^{-3}\right)$. Levels of TOC content in mangrove soils were recorded higher than that was recorded from the soils of inland forest systems (Donato et al., 2011). The Present study revealed that TOC values of the mangrove soils in the Batticaloa lagoon, $348 \mathrm{Mg} \mathrm{C} \mathrm{ha}^{-1}$, which is twice higher than the TOC recorded for soils of tropical savanna forests, (146-198 Mg C $\mathrm{ha}^{-1}$ ) at Yap and Palau islands in Pacific Ocean (Donato et al., 2012) and Brazil, 90 - $160 \mathrm{Mg} \mathrm{C} \mathrm{ha}^{-1}$ (Moreno \& Calderon, 2011). 


\section{Conclusion}

Mangrove ecosystems in the Batticaloa lagoon which have the capacity to sequester on average, $506 \mathrm{Mg} \mathrm{C} \mathrm{ha}^{-1}$ of TOC therefore can be ranked superior among the other mangrove ecosystems in the region such as those in Okinawa, Japan of which the carbon sink capacity ranges between $57-822 \mathrm{Mg} \mathrm{C} \mathrm{ha}^{-1}$ (Khan et al., 2009), and Campeche, Mexico ranges $12-222 \mathrm{Mg} \mathrm{C}$ ha- (Cerno-Breton et al., 2011). Findings of the present study therefore contribute to the current knowledge base on functional capacities of Sri Lankan mangroves, and therefore encourages rational decision making on conservation and management of mangrove areas for their ecological services including their carbon sequestration function and contribution to mitigate anticipated climatic changes. They also could contribute to make more accurate estimations on stocks of sequestered carbon required for carbon trading purposes such as those initiated by the United Nation's REDD+ (Reducing Emissions from Deforestation and Forest Degradation, Conservation and Enhancement of Carbon stocks, and Sustainable Management of Forest) facilities.

\section{References}

Alongi, D. M. (2009). The energetic of mangrove forests. Springer Science Business media B.V., pp 211.

https: / / doi.org/ 10.1007/978-1-4020-4271-3

Alongi, D. M. (2011). Carbon payments for mangrove conservation: ecosystem constraints and uncertainties of sequestration potential. Environmental Science and Policy, 14(4), 462-470. https://doi.org/10.1016/j.envsci.2011.02.004

Amarasinghe, M. D. \& Balasubramaniam, S. (1992). Structural properties of two types of mangrove stands on the northern western coast of Sri Lanka. Hydrobiologia. 247, 17-27. https://doi.org/10.1007/BF00008201

Amarasinghe, M. D. \& Perera K. A. R. S. (2017). Historical biogeography of mangroves in Sri Lanka. Ceylon Journal of Science, (Special Issue) 46, 111-117. 
K. A. R. S. Perera \& M. D. Amarasinghe

http://doi.org/10.4038/cjs.v46i5.7458

Anderson, J. M. \& Ingram, J. S. I. (eds.) (1998). Tropical soil biology and fertility, A Handbook of methods, CAB publishing, UK.

Banerjee, K., Sengupta, K., Raha, A. and Mitra, A. (2013). Salinity based allometric equations for biomass estimation of Sundarban mangroves, Biomass and Bioenergy, 56, 382-391. https://doi.org/10.1016/j.biombioe.2013.05.010

Ceron- Breton, J. G., Ceron- Breton, R. M., Rangel-Marron, M., Muriel-Garcia, M., Cordova-Quiroz, A. V. \& Estrella-Cahuich, H. (2011). Determination of carbon sequestration rate in soil of a mangrove forest in Campeche, Mexico, International Journal of Energy and Environment, 5(3), 328-336. www.naun.org/main/NAUN/energyenvironment/19-1165.pdf

Cintron, G. \& Schaeffer-Novelli, S. Y. (1984). Methods for studying mangrove structure, In: Snedaker, S. C. \& Snadaker, J. (eds.), The mangrove ecosystem: research methods, UNESCO, Paris, 91-113.

Chokkalingam, U. \& Vanniarachchy, S. A. (2011). Sri Lanka's REDD+ potential: myth or reality? Forest carbon Asia country profile report No 1: Sri Lanka.

Clough, B. F. (1992). Primary productivity and growth of mangrove forests. In: Robertson, A.I. \& Alongi, D.M. (eds.), Tropical mangrove ecosystems, American Geophysical Union, Washington, USA, 225-249.

URI: http://epubs.aims.gov.au/11068/3025

Coronado-Molina, C., Day, J.W., Reyes, E. \& Perez, B.C. (2004). Standing crop and aboveground biomass partitioning of a dwarf mangrove forest in Taylor River Slough, Florida, Wetlands Ecology andManagement, 12 (3), 157-164. https://doi.org/ 10.1023/B:WETL.0000034071.17156.c0

Comely, B. W. T. \& McGuinness, K. A. (2005). Above and below ground biomass and allometry of four common northern 
Australian mangroves, Australian Journal of Botany, 53, 431436. https:/ /doi.org/10.1071/BT04162

Crooks, S., Herr, D., Tamelander, J., Laffolet, D., \& Vandever, J. (2011). Mitigating climate change through restoration and management of coastal wetlands and nearshore marine ecosystems: Challenges and opportunities. Environment Department paper 121, World Bank, Washington, DC:

Dayarathne, V. T. K. \& Kumara, M. P. (2013). Variation of Mangrove Above-ground Dry Biomasses in Relation to Anthropogenic Disturbances, Proceedings of the International Forestry and Environment Symposium 2013 of the Department of Forestry, 21. https: / / doi.org/ 10.31357/ fesympo.v18i0.1874

Dissanayake, W. A. S. S. Ranasinghe, D. M. S. H. K. \& Wahala, S. (2009). Estimation of carbon stock in Kandyan homegardens located in Kandy and Matale districts in Sri Lanka, Proceedings of the 14th International Forestry and Environment symposium, University of Sri Jayawardenapura, Sri Lanka. 375.

https:/ / doi.org/ 10.31357/fesympo.v14i0

Dittmar, T., Hertkorn, N., Kattner, G. \& Lara, R. J. (2006). Mangroves, a major source of dissolved organic carbon to the oceans. Global Biogeochem. Cycles 20, GB1012. https: / / doi.org/10.1029/2005GB002570

Donato, D., Kauffman, J. B., Murdiyarso, D., Kurnianto, S., Stidham, M. \& Kannien, M. (2011). Mangroves among the most carbonrich forests in the tropics, Nature Geoscience, 4, 293-297. https://doi.org/10.1038/ngeo1123

Donato, D. C., Kauffman, J. B., Mackenzie, R. A., Ainsworth, A. \& Pfleeger, A.Z. (2012). Whole-island carbon stocks in the tropical Pacific: Implications for mangrove conservation and upland restoration. Journal of Environmental Management, 97, 89-96. https://doi.org/10.1016/j.jenvman.2011.12.004 
Edirisinghe, E. A. P. N., Ariyadasa, K. P. \& Chandani, R. P. D. S. 2012. Forest Cover Assessment of Sri Lanka, The Sri Lankan Forester, 34 (New series), 1-12.

Gunawardena, A. R., Nissanka, S. P., Dayawansa, N. D. K. \& Fernando, T. T. (2016). Above Ground Biomass Estimation of Mangroves Located in Negombo -Muthurajawela Wetland in Sri Lanka using ALOS PALSAR Images, Tropical Agricultural Research, 27 (2), 137- 146.

http://www.pgia.ac.lk/files/Annual_co

Harris, J. M. \& Vinobaba P. (2013). Assessment the Present Status of Batticaloa Lagoon, Sri Lanka by means of Water Quality, Fish Diversity Indices and Pollution Indicating Planktons. J Biodivers Endanger Species 1,105. doi:10.4172/2332-2543.1000105

Hoque, A. T. M. R., Sharma, S. \& Hagihara, A (2011). Above and below ground carbon acquisition of mangrove Kandella obovata tree in Manko wetland, Okinawa, Japan, International Journal of Environment, 2011, 1, 7-13.

Holdrige, L. R., Grenco, W. C., Hathey, W. H., Liang, T. \& Tosi, J. (1971). Forest environment in tropical life zone: A pilot study, Pregaman Press, New York. https://lib.ugent.be/catalog/rug01:000419058

Jennerjahn, T. C. \& Ittekkot, V. (2002). Relevance of mangroves for the production and deposition of organic matter along tropical continental margins. Naturwissenschaften, 89, 23-30.

DOI: $10.1007 / \mathrm{s} 00114-001-0283-\mathrm{x}$

Joshi, H. \& Ghose, M. (2003). Forest structure and species distribution along soil salinity and $\mathrm{pH}$ gradient in mangrove swamps of the Sundarbans, Tropical Ecology, 44(2), 197-206. tropecol.com/pdf/open/PDF_44_2/44207.pdf

Joshua, L. B., Joseph, M. S., Thomas, J. S., Christian, J. S. \& Armando, H. (2012). Organic carbon burial rates in mangrove sediments: strengthening the global budget. Global Biogeochem. Cycles 26, GB3011. 
https://doi.org/10.1029/2012GB004375

Kairo, J. G., Lang at, J. K. S., Dahdouh-Guebas, F., Bosire, J. \& Karachi, M. (2008). Structural development and productivity of replanted mangrove plantation in Kenya, Forest Ecology and Management, 255, 2630-2677.

https://doi.org/10.1016/j.foreco.2008.01.031

Karunathilake, K. M. B. C. (2003). Status of mangroves in Sri Lanka, Journal of Coastal Development, 7, 5-9.

https:// ejournal.undip.ac.id/index.php/coastdev/article/vie $\mathrm{w} / 383$

Kathiresan, K. \& Khan, S. A. (2010). International Training Course on Costal biodiversity in Mangroves: Course manual, Annamalie University (CAS in Marine Biology, Parangipettai), India. $744 \mathrm{pp}$.

Kauffman, J. B., Heider, C., Cole, C. T., Dwyer, K. \& Donato, D. C. (2011). Ecosystem Carbon Stocks of Micronesian Mangrove Forests, Wetlands, 31,343-352.

https://doi.org/10.1007/s13157-011-0148-9

Khan, N. I., Suwa, R. \& Hagihara, A. (2009). Biomass and aboveground net primary production in a subtropical mangrove stand Kandelia obovata (S.L.) Yong at Manko wetland, Okinawa, Japan, Wetlands Ecology \& Management, 17, 585-599. https: / /doi.org/10.1007/s11273-009-9136-8

Komiyama, A., Poungparn, S. \& Kata, S. (2005). Common allometric equations for estimating the tree weight of mangroves, Journal of Tropical Ecology, 21, 471-477.

https:/ / doi.org/10.1017/S0266467405002476

Komiyama, A., Ong, J. E. \& Poungparn, S. (2008). Allometry, biomass and productivity of mangrove forests: A review, Aquatic Botany, 89, 128-137. https://doi.org/10.1016/j.aquabot.2007.12.006

Kotagama, S. W., Pinto, L. \& Samarakoon, J. L. (1998). Country report Sri Lanka, In: Scott, D. A. (Complied), A Directory of 
K. A. R. S. Perera \& M. D. Amarasinghe

Asian Wetlands, Ramsar Site information services, Biodiversity Ecological Networks, Wetlands International, Netherlands.

Kusmana, C., Sabiham, S., Abe, K. and Watanabe, H. (1992). An estimation of above ground tree biomass of a mangrove forest in east Sumatra, Indonesia, Tropics, 1, 243-257. https://doi.org/10.3759/tropics.1.243

Moreno, A. N. M. \& Calderon, J. H. M. (2011). Quantification of organic matter and physical-chemical characterization of mangrove soil at Hooker Bay, San Andres Island- Colombia, Proceedings of the Global conference on global warming, July, Portugal, 1-8.DOI:10.3923/jest.2016.198.207

Ong, J. E. (1993). Mangroves - a carbon source and sink, Chemosphere, 27, 1097-1107.

https://doi.org/10.1016/0045-6535(93)90070-L

Perera, K. A. R. S., Sumanadasa W. A. \& Amarasinghe M. D. (2012). Carbon retention capacity of two mangrove species, Bruguiera gymnorrhiza (L.) Lamk. and Lumnitzera racemosa Willd. in Negombo estuary, Sri Lanka. Journal of the Faculty of Graduate Studies, University of Kelaniya, Sri Lanka. 1, 56-70 pp. http://repository.kln.ac.lk/handle/123456789/5418

Perera, K. A. R. S, Amarasinghe, M. D. \& Somaratna, S. (2013). Vegetation Structure and Species Distribution of Mangroves along a Soil Salinity Gradient in a Micro Tidal Estuary on the North-western Coast of Sri Lanka. American Journal of Marine Science,1(1), 7-15. DOI: 10.12691/marine-1-1-2

Perera, K. A. R. S. \& M. D. Amarasinghe (2016). Atmospheric carbon removal capacity of a mangrove ecosystem in a micro-tidal basin estuary in Sri Lanka. Journal of Atmospheric Environment, 134, 121-128.

https://doi.org/10.1016/j.atmosenv.2016.03.034

Poungparn, S. (2003). Common allometric relationships estimating the biomass of mangrove forests, Ph.D. dissertation, Gifu University. 
Putz, F. \& Chan, H. T. (1986). The growth, dynamics and productivity in a mature mangrove forest in Malaysia, Forest Ecology and Management, 17, 211-230.

https://doi.org/10.1016/0378-1127(86)90113-1

Rajeeshan, S. \& Jayasingam, T. (2000). Preliminary study report on mangroves of Pankudaweli, workshop on Estuarine Biology, 24-26 March 2000, Sri Lanka.

Roberts, E. M. R., Schmitz, N., Boeren, I., Driessen, T., Herrmans, K., Mey, J. D., Casteele, E. V. D, Beeckman, H \& Koedam, N. (2011). Successive Cambia: A Developmental Oddity or an Adaptive Structure? PLoS ONE 6(1): e16558. https://doi.org/10.1371/journal.pone.0016558

Ross, M. S., Ruiz, P. L., Telesnicki, G. J. \& Meeder, J. F. (2001). Estimating above-ground biomass and production in mangrove communities of Biscayne National Park, Florida (USA), Wetlands Ecology \& Management, 9, 27-37. https://doi.org/10.1023/A:1008411103288

Schumacher, B. A. (2002). Methods for determination of total organic carbon (TOC) in soils and sediments, NCEA-C-1282 EMASC001, Ecological risk assessment support center, Office of Research and Development US. Environmental Protection Agency.

Suratman, M. N. (2008). Carbon sequestration potential of mangroves in southeast Asia. In: F.Bravo et al. (eds.), Managing forest ecosystems: The challenge of climate change, Springer Science Business media, 297-315.

https://doi.org/10.1007/978-1-4020-8343-3_17

Suzuki, E. \& Tagawa, E. (1983). Biomass of a mangrove forest and a sedge marsh on Ishigaki Island, South Japan, Japan Journal of Ecology, 33, 231-234. https://doi.org/10.18960/seitai.33.2_231

Tamai, S., Nakasuga, T., Tabuchi, R. \& Ogino, K. (1986). Standing biomass of mangrove forests in southern Thailand, Journal of 
K. A. R. S. Perera \& M. D. Amarasinghe

the Japanese Forestry Society, 68, 384-388.

https://doi.org/10.11519/jjfs 1953.68.9_384

Twilley, R. R., Chen, R. H. \& Hargis, T. (1992). Carbon sinks in mangrove forests and their implications to the carbon budget of tropical coastal ecosystems. Water Air and Soil Pollution, 64: 265-288. https://doi.org/10.1007/BF00477106 